ARTICLE

\title{
Monsters in the dark: the discovery of Thuggee and demographic knowledge in colonial India
}

\author{
Sagnik Bhattacharya (i) ${ }^{1 凶}$
}

\begin{abstract}
The thugs have been one of the most lasting images in the portrayal of India in Western imagination. Although several scholars have questioned the authenticity of the information contained in the thug archive, that is, the corpus of colonial knowledge about the thugs, Martine van Wœrkens and Tihanyi (The strangled traveler: colonial imaginings and the thugs of India. University of Chicago Press, Chicago, 2002) and Macfie (Rethinking Hist 12 (3):383-397, 2008) argue that the very phenomenon as it was known to the British, was an orientalist construct. However, though the orientalist and romantic genesis of the thug imagery has been well established, the precise nature, reasons, and implications of the same largely remain "terra incognita". This article examines the discovery of the thugs and analyzes parts of the thug-archive through the concept of the monster as elaborated by Mary Douglas (Purity and danger: an analysis of concepts of pollution and taboo. Routledge, New York, 1966), Victor Turner ("Betwixt and between: the liminal period in rites de passage". The forest of symbols. Ithaca, NY: Cornell University Press, 1967) and Michel Foucault et al. (Abnormal: lectures at the Collège de France, 1974-1975. Picador, New York, 2003), and establishes the thug as an epistemological monster emerging from the cracks and gaps in colonial information gathering mechanisms that arose as a result of the changing nature of the Indian "state" and the employment of alien categories for demographic knowledge production. The key question here is: how can we explain the sudden appearance of thugs in the colonial archive in the 1830s and the disproportionate interest of the administration in eradicating them? This article analyzes the journalistic and legal discourse surrounding the thugs in the nineteenth century and tries to demonstrate how the notion of the "monster" can act as a methodological tool in explaining the efforts of the Thug Department. The argument is then concluded through an investigation into the implications of the discovery of the thugs for the teleology of Indian history and the consequence of "othering" tribal and other anomic populations in the new Weberian state that the colonial and post-colonial regimes envisioned to establish.
\end{abstract}

\footnotetext{
${ }^{1}$ University of Groningen, Groningen, The Netherlands. ${ }^{凶}$ email: s.bhattacharya.1@student.rug.nl
} 


\section{Introduction}

hug(s) and the crime of thuggee-highway robbery following murder by strangulation using a knotted scarf, captivated British imagination in the middle of the nineteenth century. A large part of this fascination can be attributed to Philip Meadows Taylor's 1839 novel Confessions of a Thug that popularized thug-imagery in England, as well as colonial highsociety in India (van Wœrkens and Tihanyi, 2002). Unbeknownst to him, Taylor had laid the foundation of one of the most lasting orientalist images that has not only outlived the empire that tried to eradicate its very existence, but has also made its way into the 1984 Hollywood film Indiana Jones and the Temple of Doom and several other "orientalist" portrayals of India. However, the poignant question is: who were the thugs and to what extent is the extant information about them credible, especially given that the knowledge about them is sketchy at best? I do not attempt an investigation into the actuality of the thugs but into how they were known to the British colonial administration in the midnineteenth century and and attempt to demonstrate how the metaphor of the "monster" can act as a crucial methodological tool in explaining the reaction of the British Government of India to the discovery of the thug(s).

Although the Cambridge Dictionary of English defines "thug" in the general sense as "a man who acts violently, especially to commit a crime" the word originates from the Sanskrit word thag simply meaning "a cheat." Thugs emerged in British knowledge, almost entirely through the efforts of one military-officer-turnedcivil servant William H. Sleeman around 1830 who discovered, what he believed to be, a pan-Indian network of highway criminals who murdered solely by method of strangulation by rumaal (or handkerchief) and looted travelers (Sleeman, 1836). Sleeman's thug(s) spoke a secret language or Ramasee decoding which, to Sleeman, was the key to identifying and eradicating this strange form of crime. In that attempt, he composed a dictionary of ramasee terms and produced an encyclopedic volume containing all that was known about them titled Ramaseeana: Or a Vocabulary of the Peculiar Language Used by the Thugs in 1836.

However, it is the sheer scale of the efforts and the budget employed by the administration in their attempts to root out thuggee (i.e., the crime of being a thug) that has been a matter of suspicion not just now, but even to contemporary observers writing in newspapers. What made the thugs such a dreadful obsession for the British administration that the latter was motivated to grant unchecked powers to the Thug Department (formed in the 1830s), I will argue is the elusive nature of the thugs. The very fact that British colonial law was powerless in identifying and locating them, transformed it into a "metaphor" and a personification of the fear of the "other" and the unknown. As stated before, I am not concerned with the actual positive reality of the thugs per se, as much as I am with the image of he thug(s) and with thuggee as a phenomenon as it was known to the British. The reasons for avoiding direct engagement with the positive "actuality" of the thugs is not only motivated by the fact that the largest volume of sources about them are colonial products and as such suffer from the errors and misconceptions inherent in the nineteenth century colonial knowledge production apparatus, but also because what or who the thugs were in reality is not a matter of concern anymore when the thug as a metaphor has outlived the so called community that gave birth to the notion and has entered common parlance and popular imagination.

Finally, this investigation only uses the thugs as a particular case for conclusions that may be generalized to the institution of the South Asian "state" more broadly. I will argue that invalid methods and categories of classification painted the thugs as "monsters" and created the panic surrounding the thugs in the middle of the nineteenth century and that the Foucauldian Monster as a methodological tool, helps us to understand and identify the flaws in the epistemic framework that gave rise to it. Furthermore, I will conclude by demonstrating that this discovery of the monster (in the form of the thug) in the heart of India, although was most opportune for the British Empire, created a certain narrative of Indian history that plagues the Republic of India to this day.

This means that the thug emerged from the fissures between indigenous and colonial surveillance networks; discussed by scholars working on colonial knowledge (Bayly, 1996; Cohn, 1996; Dirks, 2002) and is thus, a product of the changing nature of the "State" in South Asia. In this attempt, I locate the thugs specifically on the backdrop of the expansion of the territories of the East India Company in the 1820s and 1830s beyond the urban centers and the extention of the colonial ecumene into the heartland of India causing the necessity of cataloging the new acquisition, as well as the need to morally justify this expansion. As a justification, in the existence of thuggee, was found a perfect reason. In defeating the monster that lay at the heart of India, the East India Company-and later the British Empire, had found the perfect rationale for ruling ${ }^{1}$.

\section{The Thugs: Problems of "Discovery"}

Martine van Woerkens initiates an interesting discussion towards the end of her book The Strangled Traveler by locating the discovery of the thugs and the spread of the thug imagery within nineteenth century English romantic tendencies (van Wœrkens, 2002). This is of course a part of the debate surrounding the role of orientalist imagination in the construction or perhaps the creation of the thugs in the British colonial archive, which has been studied by Alexander Lyon Macfie who, upon examining its historiography, has highlighted the role of a "deep-seated European inclination to make an ontological and epistemological distinction between the Occident (Europe, the West) and the Orient (the East)" in the construction of the thug (Macfie, 2008, p. 384).

However, thag $(\mathrm{s})^{2}$ and phansigar(s) [literally, stranglers] feature extensively in the nineteenth century historiography of India and their existence seems to have been projected into the past as far back as the seventh century CE. The French Sinologist Stanislas Julien's account of Hiuen Tsang's [or, Xuanzang] life claimed that the Buddhist monk was captured by thags and that on two accounts he survived being sacrificed to the Goddess Durga during his travels in India between 629 and 645 CE (van Wœrkens, 2002). To the rulers of India, thags appear to have been known since at least the fourteenth century. Zia-ud-din Barani narrated the arrest and deportation of a thousand thags to Lakhnauti (Gaur) - a story uncritically repeated in Sir Henry Elliot's nineteenth century account of the history of India (van Wœrkens, 2002). Moreover, perhaps most conveniently for the European historians, thags feature prominently in Jean de Thévenot's travelogue published in 1687 (Fhlathúin, 2001). These three stories of encounters with thags are particularly important as they were referenced in William Sleeman's 1836 thug-hunting manual, Ramaseeana: Or a Vocabulary of the Peculiar Language Used by the Thugs that may well be called the core of the thugarchive [i.e., the corpus of knowledge collected by the British about thugs] and the prime interface through which the British knew the thugs.

In Ramaseeana, Sleeman (1836) identifies a hereditary, panIndian sect of the Goddess Kali (or Bhowanee) haunting the highways of India, killing and robbing travelers solely by method of strangulation (Sleeman, 1836). Sleeman's rationale for this 
unique method is divine mandate from the Goddess and he believes that indigenous rulers have for long tolerated and sometimes even supported them fearing retribution from Kali. Whether the thags referred to by Barani and Mousier de Thévenot are the same as the thugs identified by Sleeman a few centuries later, is the matter for the debate that van Wœrkens (2002) raises in her book. Máire Ní Fhlathúin (2001) inspecting Thévenot's account and its numerous appropriations in the thug archive seems to provide strong evidence to suggest that they were in fact distinctly different phenomena.

The problem essentially arises due to the use of the word "thug" or "thag" to identify them. "Thag" in its original sense only means a "cheat" or a "fraud", whereas phansigar is the more appropriate term for the British sense of the phenomenon. This distinction was not only used by pre-colonial authors and authorities (as they are named as the latter by the Emperor Jahangir in his memoir (Price, 1829, p. 57)), but also appears to have been made early in the thug archive but lost in later accounts. Dr. Richard Sherwood's early account in the Madras Literary Journal is in fact titled "Of the Murderers Called Phansigars."

Richard Sherwood was one of the first to write about the thugs and thus his account comprises one of the first entries in the thug-archives. Contrasting later knowledge with his article will actually serve to demonstrate the active process of demonization of the "thugs" that was carried out by the Thug Department and the press during the 1830s. However, the identification of the thugs as an intrinsic element in the history of India can already be noticed in Sherwood's publication.

What is important to acknowledge here, is the inherent orientalism that has been rightly highlighted by Macfie (2008) in the colonial reconstruction of the Indian past. In his discussion of this issue, Gyanendra Pandey (1997) notes the deliberate choice on the part of European historians in their selection of places, episodes, and elements as paradigmatic and characteristic of Indian history. These places such as Varanasi (Benaras) and elements such as thugs were used to highlight the distinct "otherness" of India to the European readers and thus a narrative of continuity, at least for the thugs, that the historians discovered in the writings of Thévenot was capitalized to the full extent in order to promote thuggee as an intrinsic element of India. Thus, the quoting of historical precedence in Sleeman's volume should neither surprise the reader, nor should it be read as innocent.

Fhlathúin (2001, p. 33) traces these references to Thévenot to a single paragraph in the chapter titled "Of the Province or Town of Dehly; or Gehan-Abad" in his travelogue. There, thags are described as follows:

Though the road I have been speaking of be tolerable, yet it hath many inconveniencies. One may meet with Tygers, Panthers, and Lions upon it; and one had best also have a care of Robbers [...] The cunningest of Robbers in the World are in that Countrey. They use a certain Slip with a running-noose, which they can cast with so much slight about a Man's Neck, when they are within reach of him, that they never fail; so that they strangle him in a trice...

Thévenot then proceeds to state that these robbers often send out handsome women "who with her Hair disheveled" pretends to be in danger. Although Sleeman found no evidence of thugs using women to deceive their victims, he hid this incommensurate gap between the two conceptions by inventing or pretending to possess knowledge about the temporal development of the practices of the thuggee-claims Fhlathúin (2001).

Interestingly, Thévenot neither mentions the word "thug" nor does he reveal his sources for information about them. Most importantly, he does not mention which road he was alluding to causing Sherwood (1820, p. 276-277) to interpolate the words "from Delhi to Agra" into Thévenot's statement for identifying the road when he reprinted this paragraph in his article (Fhlathúin, 2001). Although it is reasonable that Thévenot might have been talking about the trunk road between Delhi and Agra, it is equally probable that it was Sherwood's invention as that same road was also the lifeline for the East India Company's trade in Northern India and Company officials were always too anxious to secure it (Bayly, 1996). Whether Sherwood invented the location for the thugs or not, his article, first featuring in the Madras Literary Gazette in 1816 and in Asiatic Researches in 1820, was reprinted by Sleeman in his manual, Ramaseeana that became one of the founding documents of the thug-archive.

Sherwood's early nineteenth century article also differs from the later source material on thugs as he writes, "many persons, for instance, deprived by the declensions of the Mohammedan power of their wonted resources, were tempted to resort to criminal courses" (Sherwood, 1820, p. 271) thereby at least allowing for the possibility of thuggee having an economic or social genesis. Alexander Macfie (2008) and Fhlathúin's (2001) surveys show that later accounts of thugs do not allow any such considerations and stress their religious inspiration-completely depriving them of any rational basis. Macfie (2008) also points out that in spite of the crime committed by the thugs having two distinct components, i.e., murder and theft, an inordinate degree of importance is ascribed to the former.

This is not surprising if one notices the elaborate attempts made to portray thuggee as a unique form of crime, suppression of which requires the initiation of an unprecedented degree of legal involvement with the native population, which is the topic of Radhika Singha's (1993) seminal analysis of the thug campaign through the vantage point of law. Desperate attempts to portray thuggee as unprecedented and requiring massive investment and a near obsessive degree of involvement of the colonial state can be noticed in the thug-archive.

However, even amidst the vast amount of material circulating in the Bengal press of the 1830s, Fhlathúin's (2001, p. 132) survey found only one newspaper correspondent ever being critical or even skeptical to some degree about the mass hysteria that was spread in the name of the thugs. In September 1836, the Bengal Harkaru published a correspondence suspecting

"the authenticity of many of those cases of murders, robberies, \&c laid at the doors of [...] thugs. A hot hue and cry is kept up on the subject, and with all fears and wonderment directed towards Thugs."

The correspondent further states that while immense labor was being expended on eliminating the thugs, regular criminalsdescribed with the phrase "other rogues going under usual denomination", are committing various crimes nevertheless. This statement on the one hand asserts that the thugs were not the only criminals in an otherwise crime-free subcontinent justifying the investment of a majority of the available resources in hunting them down; and on the other hand, that even to the general public not associated with the administration or the Thug and Dacoity Department, thuggee was either presented or portrayed as a special (or, un- "usual") case of legal contravention.

The justification by the government in favor of such allocation of resources almost entirely rests on this "special nature" of the thugs, which motivated the former to introduce innovative instruments of the law that will be discussed later. Both Macfie's (2008) and Brown's (2002) arguments essentially start from this portrayal of the thugs as "special" and it is in fact the first instance that raises suspicion. While isolated instances of murder and theft motivated by economic hardships are the explanation for thuggee in the 1810 s and $1820 \mathrm{~s}^{3}$, a unique race committing a "monstrous" 
and "anomalous" crime, skilled in murder and an organized system to facilitate it are some of the attributes that surround the thugs in the 1830s. It is in the chronologically incoherent data about the thugs that when juxtaposed against each other (Sherwood's article versus Sleeman's book) demonstrates a development guided by growing anxiety and increasing severity and particularity of the crime. This, along with the colonial state's obsession with them (even to the extent where the native population started doubting its authenticity) is what I argue is the chief indication that the thug(s) in the colonial archive were a construct and not so much an empirical reality. The later hyperbolic, distorted and exaggerated image of the thugs is also cogent evidence in favor of Macfie's (2008) argument identifying the thugs as an orientalist construct in the sense of the word elaborated by Edward Said (1978).

However, I refrain from branding this portrayal purely "orientalist" and hence reject the suggestive conclusion of Macfie (2008) as his argument implies a construction of the thug that was intentional and premeditated for justifying the expansion into the Indian heartland. In the following pages, I will argue that the construction of the thug was but a consequence of that expansion and of the failed attempts to see "India" through Victorian lenses. A failure, which resulted in the production of a monster.

\section{The Thug as monster}

Semantically speaking, the word "monster" itself appears but once in Sleeman's (1836, pp. 47-48) Ramaseeana in the statement by the Government in its observations on the trial of the "Mahidpore gang" that "the hand of these inhuman monsters being against every one, and there being no country [...] in which they have not committed murder." However, is the term "monster" here merely a metaphor and a hyperbolic adjective or is it an actual acknowledgment of their nature as the British administration understood it-an enigma?

The monster as enigma. An enigma, can be defined from Aristotle's Poetics as a "conjunction of opposites, the mixing of [the] un-mixable" (Arvanitakis, 1982, p. 260). In simple terms, an enigma is the simultaneous exposition or association of two entirely dissimilar and mutually exclusive entities-a transgression of the natural order. This understanding of an enigma can be, and has been, (Nuzzo, 2013) used to understand the "monster" in classical philosophy as something that involves a mixture of incommensurate elements. The threat that the monster poses is the same epistemological threat that is the topic of discussion in Victor W. Turner's (1967) and more famously Mary Douglas' (1966) core works surrounding the definition of what is "pure" and the exposition of the "danger" from that what is not.

Mary Douglas (1966) had outlined the fundamental notion that it is the ability to classify (and thereby "know") something that renders it pure; conversely that which cannot be fitted into any cogent known mode of classification-objects that are in Turner's (1967) words "betwixt and between," are perceived as threatening and dangerous. Michel Foucault's lecture at the College de France on January 22, 1975, elaborated and extended this notion to animate beings-associating with it, the concept of the "monster." The Foucauldian monster, however, is an epistemological one that poses a cognitive threat to the assurance-of reliable knowledge of the world he or she inhabits, and from that resulting anxiety, the monster presents itself as a "threat to knowledge" and exposes its limitations (Foucault et al., 2003).

The monster achieves this by challenging the foundations of knowledge and "knowability" that rests on the binary logic of identity and difference. However, the monster, being an enigma, violates that binary category and does not allow classification to develop, thereby finding its place only in the undifferentiated category of "monster" and exposing the inadequacy of classification models such as those based on physical appearance, or among humans-on class, sex, religion etc. A notable example of this is the monstrosity of the hermaphrodite body (that can neither be classified as "male" nor "female": thus unclassifiable and unknowable) that Foucault explored in his 1975 lecture on the Abnormal (Foucault et al., 2003).

The threat that the monster presents to knowledge must be "neutralized" and Foucault suggests three reactions that the monster elicits from the State namely "violence, the will for pure and simple suppression or medical care or pity" (Foucault et al., 2003 , p. 56). In classical metaphysics however, this neutralization has been achieved by placing the monster in a physically differentiated space such as in the wilderness or in the unexplored reaches of the oceans whereby the monster being located "outside" the sphere of the known world causes it to cease being a threat to the foundations of that corpus of knowledge and knowledge system. The limit of thought is thus imputed into actual marginal space whereby the forest, ocean or wilderness then transforms from simply being a geographical space to an "epistemological space" defined in binary relation to the its ontological other-the sphere of the knowledge (Nuzzo, 2013, p. 57).

Historicizing the Thug "Discovery". So how can this notion of the epistemological monster be used to explain the thugobsession of the Government of India in the 1830s? Knowing the Foucauldian monster, demonstration of the thug as one will necessarily begin with the prime interface that the colonial government had with the thugs-information obtained through a network of informers and approvers that Sleeman and the "Thug Department" recruited. This is in line with Fhlathúin's (2001, p. 32) argument that "information is [was] the currency in all aspects of British dealings with the thug." Seeing it as a product of faulty knowledge creation, Christopher Bayly's (1996, p. 174) claim that the thug phenomenon was essentially an "information panic" can actually be contextualized.

Mark Brown (2002) claims that in 1765 following the Battle of Buxar, the East India Company was effectively handed a "poisoned chalice", which although offered the vast wealth of India, also required the conduct of civil and political administration in a terrain largely unknown to its merchants and traders. However, administration would mean classifying, categorizing and codifying the diversity that the subcontinent held in its belly. Moreover, in the 1830s, not only was British territory expanding rapidly, so was the Company's governmentality and administrative inclinations. Two cases of such classification would suffice to demonstrate the general methodological fallacy of these endeavors before I delve into the specific case of the thugs.

First, there is the case of the employment of European classification models in Afghanistan by Mountstuart Elphinstone. Hopkins (2008) describes Elphinstone's nineteenth century attempts to categorize and describe the "Afghan tribesmen" and the role of his understanding of Scottish highland society in that process. Elphinstone, trying to read into the Afghans what he saw in Scotland, overestimated the role of kinship in tribe-formation and this may serve as a good example of misconceptions generated due to assumption of similarity and the application of a system of classification that is alien to the population being studied. Elphinstone understood the tribe as genealogically constructed and although modern anthropological theory has modified this notion, Hopkins (2008) maintains that the idea of kinship (biological or "fictive") still dominates the understanding 
of Afghan tribal society; thus not only solidifying a genealogical and narrow understanding of the tribe but also downplaying the role of performance in one's identity ${ }^{4}$.

Secondly, there is the case of the recording of caste in the Madras Presidency by Dr. Francis Buchanan. Buchanan's original commission in 1800 made no reference to charting caste and caste relations but required of him to record "the different sects and tribes of which the body of the people is composed [of]" (Dirks, 2002, p. 116). However, his journal makes several references to caste and some attempt at caste-categorization of the population seems to have been undertaken, which led him to classify them in terms of the four "varna(s)" mentioned in Hindu scripture and the rest of the population in terms of "tribes" and "sects" or "nations"-notions completely alien in an Indian milieu (Dirks, 2002, p. 117). Nicholas Dirks (2002) notes that the application of such categories of classification can also be noticed in Colin Mackenzie's survey of Mysore, which lists the bulk of the population as "soodra" glossing over the intricacies and nuances of caste identities. In addition to the usage of alien sociological concepts such as nations and sects, a strong reliance on scripture and ignorance of practice also seems to be directing the categorization of castes in Buchanan's catalog. This reliance on scant "official" or elite sources of information, as well as the application of invalid terms of classification will be at the heart of identifying the thugs in central India three decades after Buchanan.

Mark Brown (2002), for his article on the discovery of the thugs, details the general patterns and necessities that drove the process of knowledge production about India (such as those described above) in the 1830s and highlights how they were inherently problematic. He outlines Cohn's (1996) assertion that British colonial epistemology sought to "know" the colony and the metropole within the same conceptual framework and in that vein the early empire witnessed a circulation of demographic ideas-particularly the concept of caste as hereditary occupationbased groups exhibiting distinct characteristics. Brown (2002) cites Tobias' example of an 1829 explanation of the genesis of London's criminal class where the unidentified author writes that "they are born [thieves], and it is their inheritance: they form a caste of themselves, having a particular slang..." (Tobias, 1967, p. 53) alluding to the appropriation of the concept of caste beyond its original context and a downplaying of the geographical and historical development and dynamics of caste.

The three previous cases in this section, together paint a picture of British colonial epistemology that saw the metropole in terms of the colony (i.e., through caste) and the colony through the lens of the metropole (i.e., through sects, tribes, nations, religions etc.) and herein emerged the monster. James C. Scott (2009) has argued at length, albeit through the case of highland Southeast Asia how frustrating colonial attempts at cataloging population diversity through their known modes of classification have been -often resulting in the ethnogenesis of new "tribes" and "nations" in regions, which lacked them completely. In the thugs, can be seen a similar case of frustration. The thugs came from both Hindu and Muslim backgrounds and hence were impossible to classify in terms of religion and traditional caste boundaries were also blurred when it came to the them-as the thug-archive suggests that people of various "respectable professions" worked part-time as thugs (not to mention the additional confusion engendered by the colonial understanding of the caste system as scripture-based, static, fourfold and rigid).

The obsessive focus on the language used by the thugs is also interesting as similar obsession is noticed by Scott (2009) in the attempts at classifying the Burmese highland tribes; where at the transgression of all other forms of classification, British colonial officials tried using language as the primary mode of recording tribes. Sleeman too, insists on the existence of one pan-Indian language used by the thugs in order to communicate with each other undetected by the victim present in their midst. In fact, for Sleeman the decoding of this secret language was the key to suppressing thuggee, which prompted him to name his manual in the name of this artificial language-"Ramasee." This is an interesting revelation as the feasibility of such a pan-Indian language has been doubted by several scholars, including Kim Wagner (2004) and Martine van Wœrkens (2002); and Macfie's (2008) suspicion that it is perhaps nothing but Hindustani slang, deserves some deliberation.

Historically, the discovery of thuggee can be scrutinized and the emergence of the monster explained in the following way: as the colonial state entered into the heartland of nineteenth century India, they were for the first time, encountering the true diversity and coming to terms with the enormousness of the task of governing India and forging a "state" where the fall of the Mughal empire and the Maratha Confederacy had left a vacuum. This intrusion into India also presents the first major point at which the colonial state actually stepped out of its urban core and reached into the periphery (forests, highlands etc.) without the aid of an immediate collaborator and thus found itself perplexed by the reality. The formal Persian, Urdu, Bengali or Hindustani that the officials were taught at Fort William College (Calcutta) might have sufficed for matters of administration in the urban centers of the three Presidencies and in dealings with their native collaborating rulers or agents, but in the interiors of India the languages mixed and increasingly became an unintelligible slang that was beyond the comprehension of the Company's servants. Ranajit Guha's (2002 [1993]) research highlights the severe limitations of the colonial state in ruling the countryside or even incorporating it within the same ecumenical system within which it functioned. This incorporation can only be expected to weaken and gradually become non-existent as one approached the forests and highlands.

The monster, as Foucault et al. (2003) discussed transgresses the binaries of the knowledge system and essentially makes knowledge impossible while at the same time creating the necessity for information in order to overcome the anxiety it causes by exposing the inadequacy of knowledge. The thugs fit within this definition, as British attempts at classifying them in terms of "nations," "races" or by languages and religions seems to have been frustrating failures causing them to be identified by a generic term "thug." As regarding the expansion of the horizons of knowledge, Fhlathúin's (2001) assertion that "information is the currency in all aspects of British dealings with thuggee" speaks volumes. That the existence of the thugs caused the initiation of relentless attempts to "know" this phenomenon, and the geographical and human space it occupied more generally cannot be argued against.

The desire to know, record and catalog this region is in fact well-founded in the archival record of the time. John William Kaye (1853) in the course of his The Administration of the East India Company: A History of Indian Progress remarked how recent the origins of the desire to know more about India and its people in order to better administer the region was. It is not unreasonable to imagine that anomalous elements such as the thugs effectively were responsible in the generation of this desire.

Furthermore, the thug's monstrosity is also revealed by the position it occupied in the British understanding of India. Spatially, the thug is found on the margins of the empire, in areas beyond the control of the Company or their collaborators. This lack of official state control over highlands, forests or highways is not new in the history of South or Southeast Asia; however, their position beyond the epistemic reach of the administrators is essentially novel. Traditional pre-colonial governments were wary 
of their inability to rule these areas directly and administered them with the help of tribal, nomadic or local chiefs (Luiz, 1962, pp. $109-110)^{5}$. Moreover, it is precisely here, at the juncture between embodied forms of knowledge practiced by the local populations, and the institutionalized forms of knowledge privileged by the emerging Weberian state that Christopher Bayly (1996, p. 174) identifies the development of "information panics" that he claims to be at the root of the thug-phenomenon. Bayly correctly identified the root of the panic in Etawah between 1808 and 1815 (the latter being close to the date of Dr. Sherwood's article) and claimed that the thug emerged from "the feeling of the fledgling colonial administration that they knew nothing of local society and that the locals were combining to deny it information" (Bayly, 1996, p. 174)-a physical manifestation of the anxiety caused by the lack of knowledge.

The anxiety experienced when facing the forests or highlands by the state is also not a new phenomenon as similar attitudes can be gauged in the portrayal of the wilderness by pre-colonial governments; but with the advance of the colonial state into the wilderness, the banishment of the monster to the "outside," thereby neutralizing the threat it poses to the foundations of knowledge became increasingly impossible. The thug, was now very much a part of the colonial state posing a threat to the emerging polity (by challenging the ecumenical narrative) and invoking the "will to pure and simple suppression" as Foucault predicts. This threat is not only epistemological but also actual as Brown (2002) notes in his article; the colonial state, in suppressing the thug was essentially trying to establish itself by monopolizing forms of organized violence in Weberian tradition.

The Foucauldian monster, as Nuzzo (2013) discusses, is not only neutralized in spatial terms but also through temporal banishment. This explains the extensive attempts by Sleeman in identifying a continuum between the thugs written about by Barani, and Thévenot and those discovered by him; although in the latter case he found it difficult to establish this link. Macfie (2008) explains this as an attempt to historically establish thuggee as a phenomenon predating British colonial rule thereby absolving themselves of the possibility that the impoverishment caused by extractive policies led to the development of highway robbery. However, the projection of the thugs in fact is not only limited to pre-colonial rule. A large volume of materials within the thug archive suggests along the same lines as the Irish Penny Journal which in April 1841, published a rather long article captioned "The Thugs" - that thug practices have been "in vogue from time immemorial" 6 .

This is consistent with the monstrosity of the thugs. As touched upon earlier, the threat to knowledge embodied in the monster has been traditionally neutralized through spatial or temporal banishment. Either the monster has been relegated to the margins of the known world in works such as the geography of Pliny ${ }^{7}$; or, have been located in a time before the advent of humans or the "present world" such as the Titans in Hesiod's Theogony. With the encroaching of the colonial state into the Indian heartland, the spatial banishment that might have been successful in neutralizing the threat from such anomalous elements in pre-colonial times was rendered impossible. The only remaining option was the temporal banishment and complete eradication, which Foucault et al. (2003) suggests is the normal reaction from the state to the presence of the monster. By putting an end to thuggee, the British aspired to defeat the titans at the heart of India and make the earth (i.e., India) fit for civilization.

In the remainder of the article, I will argue that the discovery of the "thug" fundamentally attempted to rewrite and realign the teleology of Indian history that has consequences to this day in the understanding of tribal populations by the post-colonial state.
Finally, it is in the sphere of the law that we find the most convincing arguments for the monstrosity of the thugs. Foucault's monster is a legal enigma that shows temporal development in its nature (from a biological one in middle ages to a moral enigma by the nineteenth century). The laws that were instituted to suppress thuggery displayed, as Radhika Singha (1993) argues in her article, unprecedented legal innovation. The series of acts beginning with Act XXX of 1836 not only gradually increase the sphere of activities of the Thug and Dacoity Department but also show an interesting discourse culminating in the Criminal Tribes Act of 1871.

This legal innovation was necessary as the laws existing prior to that were increasingly failing to address the problem of the ambiguous nature of the thugs. The thug was neither Hindu nor Muslim making the application of a highly confessional legal system difficult. In order to address thus, the 1836 law specifically stated that no futwa from any law officer will be required in the prosecution of persons accused of being a "thug" (Singha, 1993) Nor does the law specify what the crime of thuggee actually is, merely stating that:

whoever shall be proved to have belonged, either before or after the passing of this Act, to any gang of Thugs, either within or without the Territories of the East India Company, shall be punished with imprisonment for life, with hard labor.

Subsequent acts demonstrate the growing knowledge of thuggee and also a greater understanding of the Indian social reality. Not only do the newer acts (such as Act XVIII of 1837, Act XVIII of 1839 or Act XVIII of 1843) demonstrate more clarity in terms of the crime and circumstances under which it can be prosecuted, the gradual inclusion of "dacoity" within its purview is construed by Brown (2002) as evidence of the disappearance of the thug with increasing reliable knowledge. Brown (2002, p. 93) writes: "as colonial knowledge of the Indian subject developed, its catalog of real or imagined threats to British authority began to multiply in kind. In this context the image of thuggee as a quintessentially Indian crime shrank in the face of its stronger competition." Foucault's monster pushes the limits of knowledge-it appears, so does the thug.

The thug is a nomad and hence not a definable subject of either the Company which, relying on European physiocratic notions of territoriality, understood the geography of India, both physical and human, in terms of its land revenue policies as discussed in detail by Nicholas Dirks (2002); nor was it a subject to the territories of the Native Princes; thus, transgressing the law and exposing its inadequacies in the context of the growing desire of the colonial state to combine the two spheres by constant outward expansion. As in the case of the monster that cannot be classified and is known as an unidentifiable category by itself, the lack of operationalization of the crime of thuggee essentially creates this category-the arbitrary label of "Thug."

Yet, the thug cannot be identified. He is no different from the hundreds of other travelers along the highways and "demonstrates" his true identity only when it is too late. It is scarcely worth pointing out that the word "monster" has close relations to "monstrare" the Latin for "to demonstrate." Furthermore, the method of the crime, strangulation by a scarf and the absence of an immediately identifiable murder weapon, along with the position of the crime-away from public eyes, causes the established method of evidence to fail in the case of the trial of the thugs. These trials thus almost exclusively relied on informers and "approvers" (including convicted former thugs) that the Thug Department used in order to gain "knowledge" of the crime.

It is not true that the nature of these trials went entirely unnoticed and without criticism in the political discourse of the 
day. Fhlathúin's (2004) survey shows a number of occasions when the method of dispensing justice and the nature of evidence, including the possibility that approvers and informers might be acting out of personal interest against "any guiltless object of their resentment" was critiqued and questioned. However, much can be inferred from the general rejoinder in favor of the Thug Department and its special powers: "to a crime so anomalous as this, you cannot safely or wisely apply the routine formalities of our courts of justice" (Fhlathúin's, 2004, p. 131), suggesting that even to colonial officials, and not merely to the academic reflecting on the crime in hindsight and with the benefit of epistemological theory, did it appear "anomalous" .

\section{The legacy of the Thugs: a new teleology}

The most lasting consequence of the discovery of the thugs and subsequent attempts to eradicate them came from the last piece of legislation introduced in order to control thuggee, as well as all other such anomalous populations that failed in integrate into the colonial state system (more precisely, those that the Weberian state-system failed to accommodate), namely the Criminal Tribes Act of 1871. In addition to recognizing the existence of professional and hereditary criminality, it defined "criminal tribes" as those social and ethnic groups "addicted to the systematic commission of non-bailable offenses." Here the term "addicted" is of special significance.

Although a completely physiological theory of addiction explaining it as a consequence of abnormal neurotransmitter flows in the brain was not developed in Victorian England, it is crucial to understand the close connections between morality and biology in nineteenth century Europe. Physiognomic theories such as those by Johann C. Lavater and Francis Galton posited a relationship between the biological and moral elements of Man. "Addiction" in the nineteenth century, though not entirely biological, was definitely a transgression of morality and in that capacity was bound to possess a biological substrate, for morality, in Lavater's theory was hereditary and Galton could only be cautious in suggesting a method for controlling the development of such traits through moral eugenics ${ }^{9}$.

The Criminal Tribes Act, when seen in the light of such conceptions appears to fit within Foucault's theory of the monster as a biological-judicial construct. The act required the registration and notification of populations branded as "criminal tribes" and effectively assumed power to relocate and rehabilitate such populations thereby putting moral eugenics into practice after the identification of the monster through biological means (i.e., through heredity and kinship networks.)

In addition to general denunciations of thugs as "depraved," accounts of the inhuman nature of the thugs can also be found to be rampant in the newspaper collections. Fhlathúin (2004, p. 131) notes a general trend in this and commented that "even a sentimental response to thug prisoners at their most vulnerable, in scenes of execution or other punishment, is muted or absent in the press" probably an indication of the attempts to demonize them and highlight the absence of morality and remorse in the thugs.

Much like the case of the identification of the thugs, the "criminal tribes," under the Criminal Tribes Act were also identified based on scanty evidence. Brown (2017) notes one particular case from 1872 in the North-West Frontier Province where the Legal Department noted the absence of concrete evidence in the appeal for the registration of criminal tribes there. The evidence forwarded appears to have been the general knowledge that "they are always heard of as professional thieves [...] and that on every opportunity they will steal" ${ }^{10}$.
Interestingly, the Criminal Tribes Acts have not entirely been abrogated in the Republic of India after independence but only repealed by the Habitual Offenders Act, 1952. This may in large part be because of the strong resemblance the post-colonial Indian state has with its colonial avatar. The notion of teleology discussed in the previous section, also finds expression in the way the state deals with the Indian "tribes" as is evidenced by the discourse in the Constituent Assembly of India debating provisions for the Scheduled Tribes.

The records of the Assembly show repeated mention of the "simplicity" and the state of underdevelopment of the scheduled tribes, which prescribes to the teleological framework for not only the history of the nation-state but also of populations in line with early anthropological traditions. Statements such as "the population is as yet too primitive to be able to understand or make use of the complicated procedure and law of the civil" are rampant in the records ${ }^{11}$.

To explain this treatment of the tribes and the case of other such anomic elements such as itinerant populations (i.e., the new monsters) that are not only persecuted by the state but also continue to suffer from human right violations that in many cases go unchecked by the law enforcement authorities-the police, Ganesh N. Devy (2000) cites the continued teaching of the Criminal Tribes Act in the curriculum for police training as a major reason. He claims that the police are "taught" to believe that they are born criminals, leading to their continued persecution in spite of legal safeguards against the same.

Here, the impact of the discovery of the monster in the form of the thug has a direct role to play. I have discussed how it can help us understand the periodization of the Indian past and that this has a direct relationship with the teleology and the notion of progress in Indian history. Neeladri Bhattacharya's (2009) survey of modern Indian textbooks shows the central position that "development" and the idea of progress occupy in the narrative of Indian history taught in schools. The discourse of Indian textbooks portrays Indian history as the story of the birth of the independent nation-state (Bhattacharya, 2009, p. 102)-a process that naturally leaves out elements such as tribes and nomadic communities who did not participate in big politics and the mainstream discourse-relegating them to the margins of history. It is not uncommon for a textbook to contain a chapter or two about the tribes of India or the colonial tribal uprisings; but the history of the interactions between the tribes and the formal "state" remains an issue yet to be incorporated into textbooks prescribed by mainstream schools.

In generalizing this to the Indian "state" at large, the question that might appear is whether the Weberian state existed in precolonial South Asia. The short answer would be, no. Although complex bureaucracies based on written materials, revenue networks and modes of political inheritance can be seen in precolonial polities such as the Mughal Empire or the Maratha Confederacy, an absolute "monopoly on all forms of physical coercion" that is the characteristic mark of the state according to Weber, (1978, pp. 54-66) is difficult to find in these political entities. The Mughal empire for empire, essentially functioned by means of complex and precarious negotiations with local rulersrajas, nawabs and nizams or mansabdar(s) who had the right to raise armies and only a nominal duty to fight under the banner of the emperor (Parthasarathi, 2011, p. 54; Copland et al., 2012, p. 104).

Underneath the narrative construct of the empire, these local rulers effectively formed a patchwork of administrative spheres radiating outward from the regional capitals and leaving ample marginal space between them for the thug and other such anomic elements to flourish and such monsters to be spatially banished. It 
is only with the establishment of the (Weberian) colonial state in the 1830s that an encroachment into these marginal areas was attempted with some success and the monsters that lay in that darkness, emerged.

\section{Conclusion}

Martine van Wœrkens (2002) has already initiated the literary understanding of the Thug discovery by locating them within the English romantic tradition and the fascination with all things monstrous in Victorian England. What I have attempted in this article is to argue that understanding the thugs as monsters helps further our understanding of the British obsession with them. The monster metaphor here, is a methodological tool used in order to explain a complex series of processes that made the thugs so marvelous and yet so dangerous at the same time. I have attempted this by historicizing the "discovery" of the thugs in the context of the 1830s and connecting it with contemporary attempts to catalog the Indian population and have argued how it is possible to see the thugs as a construct emerging from a failure of the knowledge production system-a classic genesis of the Foucauldian monster.

I have tried to engage with Macfie's (2008) core argument in addition to van Wœrkens' (2002) that the thugs were an orientalist construct but have further argued its precise nature-a monster born out of the shadows of the colonial state and from the cracks in the information networks the British tried to forge with the help of their Indian collaborators. The very nature of the thugs and the "information panic" that Bayly (1996) identified as their root, says volumes about the fundamental change in the nature of the "State" in South Asia as an institution in itselffrom a state that established nominal or narrative sovereignty to a state that tried to exercise actual power in the far reaches of the empire and attempted to integrate an extremely diverse group of people into a rather narrow repertoire. Furthermore, whereas Macfie (2008) concludes the reason for the obsession with the thugs as merely a fundraising strategy for the Thug Department; I argue that it stemmed from the deep-seated desire to believe that they were liberating India from itself and the monsters that lay in its bowels. As articulated before, the monster metaphor when used as a methodological tool helps explaining not only the sudden emergence of the thugs (as pre-colonial references to them are scanty at best), but also aids our understanding of the consequences of the discovery. By inventing a pre-colonial continuum, Sleeman and the colonial administration in general, was trying to justify to themselves and the Indian population the rationale of their existence there. It would not be entirely wrong to say that they had probably overdone this a little, as even the "natives", as can be read from the newspapers, began to question the narrative.

Why the thugs remain important and worth this investigation, in purely theoretical terms, is because their discovery set in motion the series of legal reforms culminating in the Criminal Tribes Acts that have left their mark to this day on the postcolonial state in India. The fear that the thugs and more specifically the press campaign of the Thug Department generated in the minds of the natives, still haunts the Republic today and can be seen in the sense of unease felt by the government and government servants in administering the forests of Central India (Shah, 2018). Moreover, given the strong Maoist movement in the region, it would be wrong to say the common populace does not share similar sentiments. Whether it is the thug or the Maoist guerrillas, the forest (Dandakaranya) and the hills (Naga hills) continue to pose a challenge to the Indian ecumenical narrative and continues to be a nightmare for the administration ${ }^{12}$.
The understanding of the thugs as a tribe, also initiated Indian colonial anthropology to some extent and more importantly, set the tone for the state-and-tribe relations that remain largely unchanged. From being partners and strategic allies of the state (Luiz, 1962; Bayly, 1996), the "forest-people" and the "tribes" were reduced to being the antithesis of the state itself-its ontological "other." It is of course worth the effort to speculate if the narrative would have been considerably different had the colonial state encountered these "anomic" (in terms of the Weberain state) elements in less threatening circumstances. Nevertheless, the new apocalyptic teleology that the discovery of the thugs helped in constructing, remains effective in the twenty-first centurycoated in the new language of "progress" and "development" that not only continue to marginalize the adivasi (i.e., tribal/indigenous) population of India, but also contribute to the widespread human rights abuses meted out to them in spite of legal safeguards.

In conclusion, I believe that I have succeeded in demonstrating the devastating long-term consequences of applying alien categories to populations, to make a case for a reevaluation of the "state" as an institution in South Asia and a reexamination of the social science theories and European terminology employed by the same in the process of demographic knowledge productionlest we create our own monsters from the shadows such alien concepts cast on the unique and complex fabric of South Asian society.

Received: 4 December 2019; Accepted: 6 April 2020; Published online: 04 May 2020

\section{Notes}

1 This argument is derived from Gayatri Chakraborty Spivak's extensive outline of the British Liberal's fascination with the idea of saving the natives from themselves.

2 Throughout this paper, I use the spelling "thag" to refer to the pre-colonial references to the phenomenon while I reserve "thug" for its colonial avatar. Thuggee is the word for the crime of being a thug.

3 The magistrate at Etawah, after interrogation, discovered three classes of thugs and concluded that they had no relation to each other (Singha, 1993, p. 117).

4 Hopkins notes that this change was reflected even within Pashtun society as members increasingly began identifying distant relative as fellow Pashtunwali but distancing them when identifying their rewaj, which constitute the performative element of Pashtun tribal identity. See: Hopkins (2008, pp. 27-28).

5 For a discussion and detailed account of the role of tribal and forest population in pre-colonial Indian polities (e.g., Kerala) see: A. D. Luiz, The Tribes of Kerala (Delhi 1962), 109-110. Bharatiya Adimjati Sevak Sangh.

6 "The Thugs," Irish Penny Journal Vol 1. No. 43 (April 24, 1841): 342.

7 Monsters appear in Pliny's Historia Naturalis, as well as in Shakespeare's Othello (Act I, Scene 3), lines 136-144.

8 The word "anomaly" is defined in the Oxford Dictionary as something "that is different from what is normal or expected" and thus as an abnormality.

9 Lucy Hartley has outlined the construction of normality through the works of Lavater and Galton from which I have inferred the relation to the theorization of "addiction." See: Lucy Hartley, "Constructing the common type: Physiognomic norms and the notion of "civic usefulness", from Lavater to Galton," In Ernst W (2006) Histories of the normal and the abnormal: social and cultural histories of norms and normativity. Routledge, London.

10 National Archives of India, Government of India (Home-Judicial) July 1872 No. 97 (A).

11 The Constituent Assembly of India Debates (Proceedings) Volume VII. Proceedings dated November 4, 1948 Section 10.

12 Alpa Shah (2018) has in fact invoked the Frankenstein metaphor in analyzing the Maoist situation in central India.

\section{References}

Arvanitakis K (1982) Aristotle's "poetics": the origins of tragedy and the tragedy of origins. Am Imago 39(3):255-268

Bayly CA (1996) Empire and information: intelligence gathering and social communication in India. Cambridge University Press, Cambridge, pp. 1780-1870 
Bhattacharya N (2009) Teaching history in schools: the politics of textbooks in India. Hist Workshop J 67:99-110

Brown M (2017) Postcolonial penality: liberty and repression in the shadow of independence, India c. 1947. Theor Criminol 21(2):186-208

Brown M (2002) Crime, governance and the company Raj: the discovery of thuggee. Br J Criminol 42(1):77-95

Cohn BS (1996) Colonialism and its forms of knowledge: the British in India. Princeton University Press, Princeton, N.J.

Copland I, Mabbett I, Roy A et al. (2012) A history of the state and religion in India. Routledge, New York

Devy G (2000) For a nomad called thief. India International Centre Quarterly 27 (2):51-60

Dirks NB (2002) Castes of mind: colonialism and the making of modern India. Princeton University Press, Princeton, N.J.

Douglas M (1966) Purity and danger: an analysis of concepts of pollution and taboo. Routledge, New York

Ernst W (2006) Histories of the normal and the abnormal: social and cultural histories of norms and normativity. Routledge, London

Fhlathúin MN (2001) The travels of M. de thévenot through the thug archive. J R Asiatic Soc 11(1):31-42

Fhlathúin MN (2004) Campaign against thugs in the Bengal press of the 1830s. Vic Periodicals Rev 37(2):124-140

Foucault M, Marchetti V, Salomoni A, Davidson AI (2003) Abnormal: lectures at the Collège de France, 1974-1975. Picador, New York

Guha R (2002) The small voice of history. In: Guha R (ed.) The small voice of history: collected essays. Permanent Black, New Delhi

Hopkins BD (2008) The making of modern Afghanistan. Palgrave Macmillan, Basingstoke

Jahangir (1829) Memoirs of the emperor Jahanguir. Translated by Price MD. J Murray, London

Kaye JW (1853) The administration of the East India Company: a history of Indian progress. Richard Bentley, London

Luiz AD (1962) The tribes of Kerala. Bharatiya Adimjati Sevak Sangh, Delhi

Macfie AL (2008) Thuggee: an orientalist construction? Rethinking Hist 12 (3):383-397

Nuzzo L (2013) Foucault and the enigma of the monster. Int J Semiotics Law 26 (1):55-72

Pandey G (1997) The construction of communalism in colonial north India. Oxford University Press, Delhi

Parthasarathi P (2011) Why Europe grew rich and Asia did not: global economic divergence 1500-1700. Cambridge University Press, New York

Said E (1978) Orientalism. Penguin Books, London

Scott JC (2009) The art of not being governed: an anarchist history of upland Southeast Asia. Yale University Press, New Haven

Shah A (2018) Nightmarch: among India's revolutionary guerrillas. Hurst and Company, London

Sherwood RC (1820) Of the murderers called phansigars. Asiatic Researches 13:250-281

Singha R (1993) 'Providential' circumstances: The Thuggee campaign of the 1830s and legal innovation. Mod Asian Stud 27(1):83-146
Sleeman WH (1836) Ramaseeana: or a vocabulary of the peculiar language used by the thugs. Huttman GH, Military Orphan Press, Calcutta

Tobias JJ (1967) Crime and industrial society in the 19th century. Batsford, London Turner V (1967) "Betwixt and Between: the liminal period in the rites de passage". In Turner, V. (ed) The forest of symbols: aspects of Ndembu ritual. Cornell University Press, Ithaca, New York

Wagner KA (2004) The deconstructed stranger: a reassessment of thuggee. Mod Asian Stud 38(4):931-963

Weber M (1978) Economy and society. Bedminster, New York

van Wœrkens M, Tihanyi C (2002) The strangled traveler: colonial imaginings and the thugs of India. University of Chicago Press, Chicago

\section{Acknowledgements}

I am grateful to Dr. Anjana Singh of the Department of History, and Dr. Peter Berger of the Faculty of Theology and Religious Studies of the University of Groningen, for their advice, comments and suggestions on improving this paper. Moreover, I would take this opportunity to thank Dr. Clemens Six and my friend Arnab Dutta for teaching and encouraging me to use methods of literary studies in historical investigations, which has greatly aided the conceptual framework of this article.

\section{Competing interests}

The author declares no competing interests.

\section{Additional information}

Correspondence and requests for materials should be addressed to S.B.

Reprints and permission information is available at http://www.nature.com/reprints

Publisher's note Springer Nature remains neutral with regard to jurisdictional claims in published maps and institutional affiliations.

\begin{abstract}
cc) (i) Open Access This article is licensed under a Creative Commons Attribution 4.0 International License, which permits use, sharing, adaptation, distribution and reproduction in any medium or format, as long as you give appropriate credit to the original author(s) and the source, provide a link to the Creative Commons license, and indicate if changes were made. The images or other third party material in this article are included in the article's Creative Commons license, unless indicated otherwise in a credit line to the material. If material is not included in the article's Creative Commons license and your intended use is not permitted by statutory regulation or exceeds the permitted use, you will need to obtain permission directly from the copyright holder. To view a copy of this license, visit http://creativecommons.org/ licenses/by/4.0/.
\end{abstract}

(C) The Author(s) 2020 